This item was submitted to Loughborough's Research Repository by the author.

Items in Figshare are protected by copyright, with all rights reserved, unless otherwise indicated.

\title{
Public-private delivery of urban water services in Africa
}

PLEASE CITE THE PUBLISHED VERSION

http://www.icevirtuallibrary.com/content/serial/mpal

\section{PUBLISHER}

(c) Institution of Civil Engineers

\section{VERSION}

VoR (Version of Record)

LICENCE

CC BY-NC-ND 4.0

\section{REPOSITORY RECORD}

Kayaga, Sam. 2019. "Public-private Delivery of Urban Water Services in Africa". figshare. https://hdl.handle.net/2134/9704. 
This item was submitted to Loughborough's Institutional Repository (https://dspace.lboro.ac.uk/) by the author and is made available under the following Creative Commons Licence conditions.

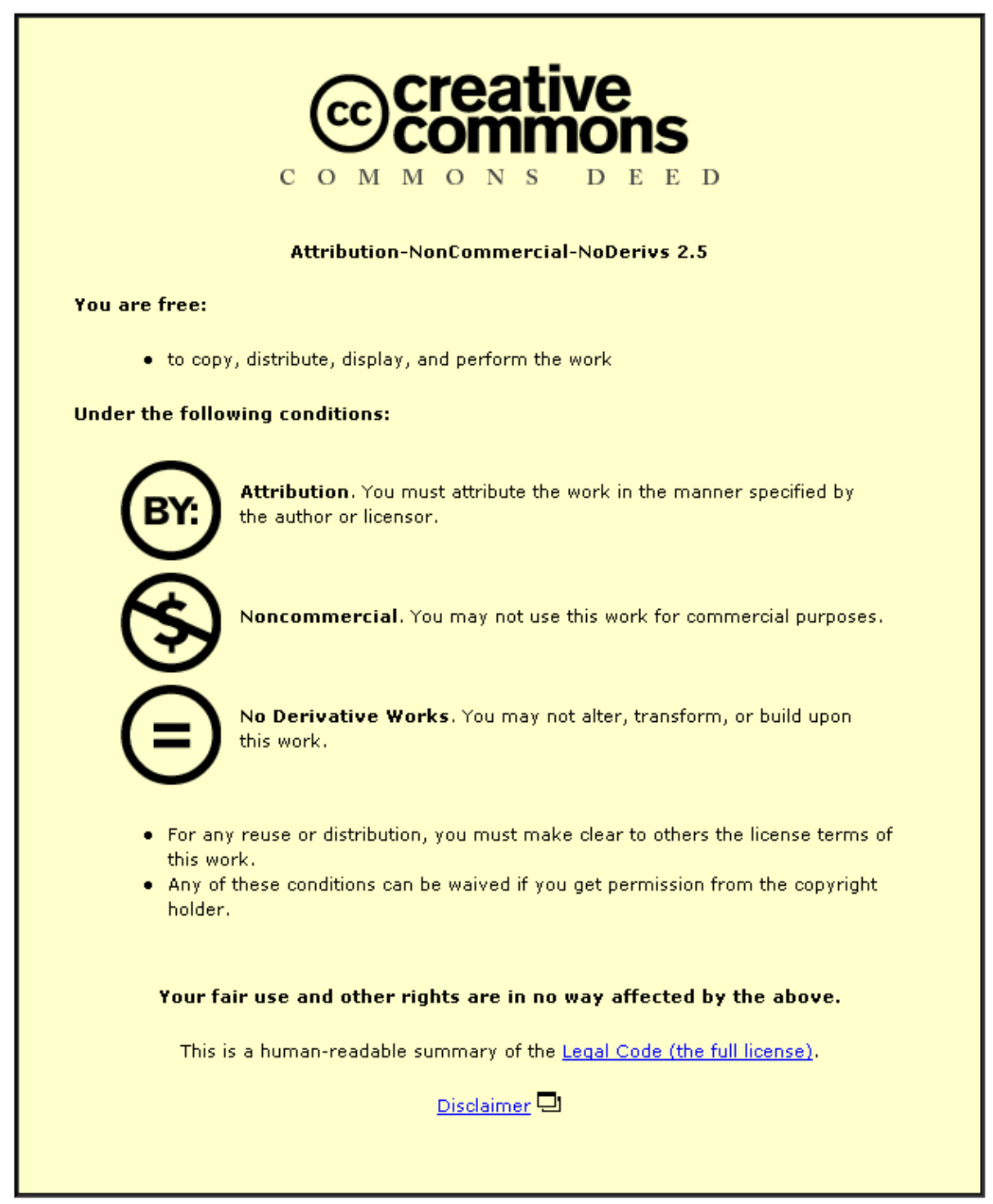

For the full text of this licence, please go to: http://creativecommons.org/licenses/by-nc-nd/2.5/ 


\section{Public-private delivery of urban water services in Africa}

S. Kayaga MSc, PhD, CEng, MCIWEM

The period between 1990 and 1997 saw a record growth in the number of public-private partnerships (PPPs) for provision of water/sewerage services in developing countries. Nonetheless, PPPs have not fared well in sub-Saharan Africa, which accounted for $\mathbf{8 0} \%$ of the PPP contracts that attracted disputes or were cancelled between 1990 and 2004. Since the 1980s, management contracts between international water operators and utilities in Africa have been promoted by the World Bank and other multi-international agencies as a model that could boost management capacity in utilities of developing countries and lead to improved effectiveness and efficiency. The present study draws upon empirical data from Kampala, Uganda and uses it as a case study to show that, on the whole, these expectations were not fulfilled. It is demonstrated that the performance improvements of the National Water and Sewerage Corporation, the utility in Kampala, were not as high as expected when it was twice managed by different international operators. On the other hand, the corporation has made impressive performance improvements under the current public management model. Conclusions have been drawn from the case study on what are the drivers of performance improvement in the water utilities of developing countries.

\section{INTRODUCTION}

The UN millennium development goals agreed upon by the world leaders at the turn of the century have become a global framework for benchmarking development in low-income countries. Target 10 of the goals is to halve, by 2015, the proportion of people without sustainable access to drinking water and basic sanitation. ${ }^{1}$ Achieving this and similar targets is a big challenge in the urban areas of developing countries, which will absorb 95\% of the $2 \cdot 02$ billion projected increase in the world's urban population during the period 2000-2030. ${ }^{2}$ Most of this population growth is being absorbed by slums. For instance, in sub-Saharan Africa (SSA), 62\% of the urban dwellers in 2005 lived in slum conditions, which is defined as lack of at least one of the basic conditions of decent housing, namely adequate sanitation, improved water supply, durable housing or adequate living space. ${ }^{2}$

State-owned enterprises (SOEs), which had been providing services in developing countries since independence, were plagued by inefficiencies and failed to expand service to meet the rapidly growing demand. ${ }^{3}$ Hence, international donor agencies, on which many developing countries have relied for infrastructure development since the debt crisis of the 1980s, initially demanded the restructuring of SOEs, and thereafter called for public-private partnerships (PPPs) in the delivery of services. ${ }^{4}$ PPPs may be defined as partnerships in which public sector bodies enter into contractual agreements with the private sector entities to construct and/or manage public sector infrastructure facilities, such as energy, water/sanitation services, telecommunications and social services (hospitals, prisons, schools, etc.). ${ }^{5}$ It was expected that the PPPs would not only attract the much needed infrastructure investments to the developing countries but would also provide a new emphasis on a proactive, performance- and commerce-oriented management. ${ }^{6}$

Reforms were carried out in earnest by the developing countries, and, since the late 1980s, international water operators have signed management, lease or concession contracts with water utilities in many developing countries. For instance, by 2005, 17 countries in SSA had invited international water operators to provide water services to their urban areas. ${ }^{7}$ Nonetheless, the number of people with inadequate service levels for both water and sanitation has been increasing. The World Health Organisation/UN International Children's Emergency Fund (WHO/Unicef) estimated that the number of urban residents in the developing regions without access to safe water increased from 107 million in 1990 to 170 million in 2004, while for sanitation, the number increased from 475 million to 611 million in the same period. ${ }^{8}$ The situation is critical in SSA where it was estimated in 2004 that only 56 and 34\% of the population had access to an improved water source and basic sanitation, respectively. ${ }^{9}$ This paper traces the introduction of PPPs in SSA, provides general trends of PPPs in the subcontinent and finally analyses the performance of the management contracts for provision of services to Kampala, Uganda.

\section{THE GENESIS OF PPPS IN UTILITY SERVICES IN AFRICA}

Urban water services infrastructure in most African countries has been state-owned since independence, although their management has changed hands. Following the footsteps of the colonial administrations, post-independence governments in Africa created SOEs to manage urban water and sewerage services, while government departments directly managed rural 
water and sanitation. Many of the African leaders were highly influenced by socialist/communist concepts during the struggle for independence, and considered government intervention in the economy a natural order of affairs. ${ }^{4}$ However, many SOEs failed to meet the expectations of their customers, governments and international funding agencies: they could neither expand the infrastructure adequately to serve the increasing urban population, nor could they efficiently operate/maintain existing infrastructure to provide good service levels to the existing customer base. $^{3}$

The poor performance of SOEs could primarily be attributed to the multiple and conflicting objectives the managers were required to achieve. For instance, SOEs were expected to operate in a commercial, efficient and profitable manner, but also be able to provide services at below-cost prices. They were also expected to generate employment for the citizens, deal with state-sanctioned suppliers, and expand services to politicallydetermined locations, all of which contradicted the first objective. Other reasons for poor performance have been cited, such as

(a) poor initial investment decisions

(b) inadequate initial and working capital

(c) poor collection efficiencies, mainly brought about by nonpaying state agencies

(d) inadequate financial reporting and monitoring systems

(e) a disabling institutional framework

(f) poor human resources capacity at managerial and technical levels. ${ }^{3,4}$

By the late 1970s, the financial performance of most urban water utilities (managed by SOEs) in SSA had deteriorated to the extent that direct budget transfers and indirect subsidies such as non-collection of taxes and social security payments could not redeem the SOEs. By the early 1980s, the financing gap became so critical that it attracted corrective action from the international financial institutions, mainly the World Bank and the International Monetary Fund. The World Bank estimated that by the early 1990s, the annual losses from inefficiencies and unsustainable pricing policies were estimated to be nearly equal to annual investment in infrastructure. ${ }^{3}$ As a solution, the international financial institutions provided structural adjustment lending loans, which in addition to supporting 'hardware' infrastructure projects also required the borrower to take measures to correct unstable imbalances in the economy, which could have been brought about by external shocks such as rapid energy price increases or the collapse of export markets. These structural adjustment loans were usually rapidly disbursed and were often accompanied by longer-term technical assistance. Africa accounted for about 70\% of the SOE-related structure adjustment projects carried out by the World Bank and International Monetary Fund in the period 1981 to $1990 .^{4}$

Prior to the disbursement, the borrowing governments had to agree to carry out a wide range of restructuring and performance improvement measures not involving ownership change, and the preparation for PPPs. The required reforms included

(a) classification of SOEs

(b) elimination of state monopolies

(c) legal and legislative reforms to make SOEs more autonomous (d) changes towards cost-based pricing

(e) human resources development including reassessment of staff levels, retraining and redeployments

(f) strengthening of financial management systems.

Whereas some commercial and manufacturing SOEs were subjected to the conditionality of privatisation, similar conditions did not apply to infrastructure utilities. ${ }^{4}$

The level at which these conditions were fulfilled varied from one country to another, and therefore had varying effects on service provision. First, tariffs were increased - although these changes did not necessarily result in a substantial financial impact, as major consumers, particularly government departments, did not pay their bills. Second, governments were relieved of budgetary burdens, although they continued to provide SOEs with guarantees for short-term loans from national banks to cover working capital. Third, there were staff lay-offs, which prompted staff to build up organised opposition and raise the political temperature against the interference of international financial institutions in the economies of the developing countries. However, in many instances, the respective governments did not honour their commitments such as match-funding the rehabilitation of the infrastructure, and did not follow through with some of the drastic and sometimes socially painful restructuring measures. For instance, performance contracts and other devices set up to minimise the interference of government bureaucrats in management of SOEs did not achieve the objectives, and set performance targets were rarely enforced or met. ${ }^{3,10}$ As a result, performance improvement, such as the one attained by Sierra Leone's Guma Valley Water Company, was more the exception than the rule. ${ }^{4}$

In addition to the dismal performance of water utilities, there were other key factors that compelled governments in developing countries to consider PPPs. During the 1980s, most economies of SSA experienced large fiscal deficits, and infrastructure services became an easy target for budget cuts. PPPs in infrastructure were sought to reduce the overdependence of SOE on the government coffers. ${ }^{3,10}$ Adoption of PPPs was also buttressed by radical economic theory that originated from the USA in the 1960s, which had inspired the American deregulation and British divestiture programmes. ${ }^{10}$ These ideas, coupled with the disappointments from SOE reform and rehabilitation measures in developing countries, sparked an international debate on the adoption of PPPs for infrastructure services. However, unlike policy makers in some developing countries (such as Latin America), governments from SSA did not take up PPPs in infrastructure out of their own choice: most SSA leaders embraced PPPs as a major conditionality for accessing international donor funds. ${ }^{4}$

\section{TRENDS AND SCOPE OF WATER SERVICES PPPS IN SSA}

Public-private partnerships for infrastructure services can take many forms and may incorporate some or all of the following features $^{5}$

(a) public infrastructure facilities are transferred to a private sector entity (with or without payment in return)

(b) the private sector entity builds, extends or renovates a facility

(c) the public sector entity specifies the operating features of the facility 
(d) services are provided by the private sector using a public sector facility for a defined period of time (usually with restrictions on operations and pricing)

(e) the private sector entity agrees to transfer the facility back to the public sector (with or without payment) at the end of the agreement.

The private participation in the infrastructure project databank maintained by the World Bank classifies the projects using the following definitions. ${ }^{11}$

(a) Operations and management contract: a private entity takes over the management of a state-owned enterprise for a given period. This category includes management contracts and leases.

(b) Operations and management contract with major capital expenditure: a private entity takes over the management of a state-owned enterprise for a given period during which it also assumes significant investment risk. This category includes concession-type contracts such as build-transfer-operate, build-lease-operate, and build-rehabilitate-operate-transfer contracts as applied to existing facilities.

(c) Greenfield project: a private entity or a public-private joint venture builds and operates a new facility. This category includes build-own-transfer and build-own-operate contracts as well as merchant power plants.

(d) Divestiture: a private consortium buys an equity stake in a state-owned enterprise. The private stake may or may not imply private management of the company.

Whereas PPPs in energy, telecommunications and transport sectors in SSA grew at a high level in the early 1990s, PPPs in water and sanitation have been less common, and the pace of reform has been slower and harder to sustain politically. ${ }^{12}$ Governments in SSA were hesitant to 'privatise' water services because of the sensitive political nature of water. Being a basic necessity, water is seen as a public good, and by some people as a gift of God, which perceptions challenge the principle of full-cost recovery for water services. ${ }^{10}$ Water services have got some other unique characteristics. Provision of water/sewerage services is a natural monopoly, for which scale economies of water production and network systems make it efficient to have one provider. Second, water/sanitation services have both positive and negative externalities, whereby benefits and costs are conferred upon those not party to the transaction; for example, public health implications and environment degradation, respectively. ${ }^{5,10}$ Fig. 1 shows the number and level of investment (categorised according to the sector) in SSA for the period 1991 to 2006. It shows that telecommunications had the largest share of PPPs whereas water services had the least number of projects and investment finance. $^{13}$

For the reasons mentioned in the previous paragraph, the governments of countries in SSA shied away from complete divesture of water services infrastructure. Whereas there were 31 PPP divesture projects in the energy, telecommunications and transport sectors in SSA between 1991 and 2006 worth US $\$ 7182$ million, no divesture project reached closure in the water/sanitation sector in SSA. ${ }^{13}$ Table 1 shows the build-up of PPP projects in the water/sanitation sector in SSA in comparison with other regions during the period 1991 to 2006. The table shows that only 22 PPP projects reached financial

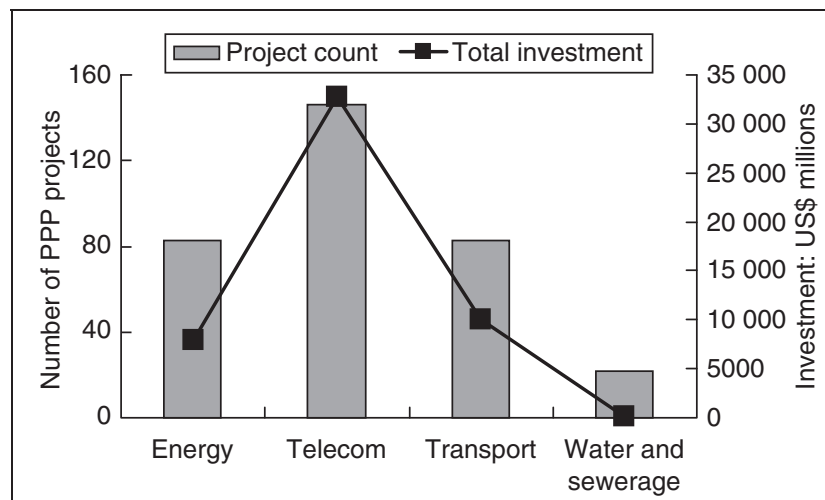

Fig. I. Number of PPP projects and level of investments in subSaharan Africa for period 1991-2006, categorised per sector: compiled using data from the World Bank ${ }^{13}$

closure for provision of water/sanitation services in SSA between 1991 and 2006. Of these, 19 projects (86\%) are/were in the form of management or lease contracts, two are under concession contracts, while only one is a greenfield project. ${ }^{13}$ The table also shows that PPP contracts reached a peak during the period 1998 to 2001, when they also attracted over US\$100 million in investment funding.

Table 1 also shows that SSA accounted for only $4 \cdot 2 \%$ of PPP projects over the period in all the regions of the world. What is even more striking is the fact that over the 15-year period, SSA projects attracted a disproportionate $0.3 \%$ of the global investment funding channelled through PPP water/sanitation infrastructure projects. ${ }^{13}$ The latter fact is not surprising, considering that management and lease contracts, which do not transfer any investment risks to the private sector entity, are the most dominant in SSA. Even then, the two multinational

\begin{tabular}{|c|c|c|c|c|}
\hline \multirow{2}{*}{$\begin{array}{l}\text { Financial } \\
\text { closure } \\
\text { year }\end{array}$} & \multicolumn{2}{|c|}{$\begin{array}{l}\text { Number of } \\
\text { projects }\end{array}$} & \multicolumn{2}{|c|}{$\begin{array}{l}\text { Investments in } \\
\text { US\$ million }\end{array}$} \\
\hline & $\begin{array}{l}\text { Sub-Saharan } \\
\text { Africa }\end{array}$ & Total & $\begin{array}{l}\text { Sub-Saharan } \\
\text { Africa }\end{array}$ & Total \\
\hline |99| & I & 2 & 0 & 75 \\
\hline 1992 & I & 6 & 0 & 284 \\
\hline 1993 & I & 12 & 0 & 6629 \\
\hline 1994 & 0 & 17 & 0 & 1362 \\
\hline 1995 & I & 18 & 0 & 1835 \\
\hline 1996 & I & 27 & 20 & 1312 \\
\hline 1997 & 0 & 39 & 0 & 10161 \\
\hline 1998 & 1 & 33 & 0 & 2327 \\
\hline 1999 & 5 & 42 & 82 & 6488 \\
\hline 2000 & I & 45 & 31 & 8589 \\
\hline 2001 & 4 & 41 & 3 & 2309 \\
\hline 2002 & 2 & 44 & 0 & 1648 \\
\hline 2003 & I & 43 & 9 & 1452 \\
\hline 2004 & 0 & 52 & 0 & 4659 \\
\hline 2005 & I & 57 & 0 & 1678 \\
\hline 2006 & 2 & 48 & 0 & 2003 \\
\hline Grand total & 22 & 526 & 146 & 52810 \\
\hline \multicolumn{5}{|c|}{$\begin{array}{l}\text { Table I. Water services PPP projects reaching financial closure in } \\
\text { sub-Saharan Africa 1991-2006: compiled using data from the } \\
\text { World Bank }{ }^{13}\end{array}$} \\
\hline
\end{tabular}




\begin{tabular}{|c|c|c|c|c|}
\hline Country & $\begin{array}{l}\text { Type(s) of contract } \\
\text { (period: years) }\end{array}$ & $\begin{array}{l}\text { Year of financial } \\
\text { closure }\end{array}$ & $\begin{array}{l}\text { Lead multinational } \\
\text { company }\end{array}$ & Remarks \\
\hline Burkina Faso & Management (5) & 2001 & Vivendi & \\
\hline Cape Verde & Concession (50) & 1999 & EdP & Distressed \\
\hline Central African Republic & Lease (I5) & 1991 & Saur & Terminated \\
\hline Chad & Concession (30) & 2000 & Veolia & Terminated \\
\hline Côte d'lvoire & Lease & 1960 & Saur & Renegotiated for 20 years in 1987 \\
\hline Gabon & Concession (20) & 1997 & Veolia & Ongoing \\
\hline Ghana & Management (5) & 2007 & Vitens & Ongoing \\
\hline Kenya & Management (2) & 1999 & Gauff & Ended \\
\hline Mali ${ }^{\prime}$ & Lease $(10)$ & 2000 & Saur & Renationalised \\
\hline Mozambique-Maputo and Motola & Lease (15) & 1999 & Agua de Portugal & Ongoing \\
\hline Mozambique - three other cities & Management (5) & 1999 & Agua de Portugal & Ongoing \\
\hline Namibia & Management & 2001 & Veolia & Ongoing \\
\hline Niger & Lease $(10)$ & 2001 & Vivendi & Ongoing \\
\hline Rwanda & Management (5) & 2000 & Lahmeya & Ended \\
\hline Senegal & Lease $(10)$ & 1996 & Saur & Renewed \\
\hline S. Africa-Dolphin Coast & Concession (30) & 1999 & Saur & Distressed \\
\hline S. Africa-Nelspruit & Concession (30) & 1999 & Biwater & Distressed \\
\hline S. Africa-Sutterheim & Lease $(10)$ & 1993 & Suez & Distressed \\
\hline S. Africa-Queenstown & Lease (25) & 1992 & Suez & Distressed \\
\hline S. Africa-Johannesburg & Management & 1999 & Suez & Ended \\
\hline Sao Tome and Principe & Management & & Sinergie & Distressed \\
\hline Tanzania & Lease & 2003 & Biwater & Terminated \\
\hline Uganda & Management (2) & 1998 & Gauff & Ended \\
\hline Uganda & Management & 2002 & Suez & Ended \\
\hline Zambia & Management (5) & 2000 & Saur & Ended \\
\hline
\end{tabular}

corporations (Saur and Biwater) with concession contracts for water services in the towns of Dolphin Coast and Nelspruit, both in South Africa, cut their investment funding by 60 and 100\%, respectively. ${ }^{7}$ Table 2 gives a summary of PPP contracts in SSA. The table shows that many PPP contracts in SSA have either been terminated or distressed. Indeed, SSA accounts for over $80 \%$ of all PPP contracts that have been terminated or attracted disputes between the period 1990 to 2004 . $^{7}$ With the small investment finance apportioned to SSA (0.3\% of global investment funding for PPPs between 1991 and 2006), these developments are not surprising given the misplaced expectations in SSA that PPPs will bring the much-needed investment financing for infrastructure expansion. ${ }^{7,13,14}$ The following section analyses the general performance of water utilities in SSA that have been managed under PPPs.

\section{GENERAL UTILITY PERFORMANCE UNDER PPPS IN SSA}

Apart from attracting investment finance to water services infrastructure, another key justification for adopting PPPs was grounded in economic theory that private sector participation would bring about the much needed efficiency gains. ${ }^{7,10}$ Studies carried out in other infrastructure services such as telecommunications, in which PPPs have induced performance improvements in developing countries, have shown that competition is more important than ownership in explaining efficiency gains. ${ }^{15}$ However, published studies conducted with water utilities in SSA have provided mixed results on the correlation between adoption of PPPs and performance improvement. Some case studies have shown improvements in labour productivity, operating costs, reliability and quality of services, and share of the population served. ${ }^{16}$ Other positive changes brought about by PPPs reported in the literature are (a) strengthening of managerial innovations in the SSA water sector, such as indexation of tariffs to the rate of inflation

(b) placing water utilities under corporate law and liberating it from the government rules and regulations

(c) tangible improvements in cost recovery. ${ }^{10}$

Whereas several studies conducted in SSA have shown evidence of positive performance trends, most published econometric analyses of the effects of water privatisation in lower-income economies show little evidence that PPPs have resulted in marked improvement in performance. ${ }^{15,17}$ Another study carried out in Africa in the late 1990s reported greater service coverage for utilities under PPPs. ${ }^{18}$ However, a study of 21 African water utilities conducted in 1995-1997 found that levels of corruption and governance were far more important in explaining difference in efficiency than PPPs. ${ }^{17}$ Similarly, findings drawn from analysis of case studies on Guinea, Gabon, Senegal and Côte d'Ivoire carried out at the turn of the century show that, on the whole, the performance of water utilities under PPPs has not changed dramatically: utilities have continued to perform well or not so well, depending on

(a) their state prior to private sector participation

(b) factors operating in the external environment. ${ }^{14}$

To advance the understanding of performance trends under PPPs, a comprehensive analysis was recently carried out on data taken from the Service Providers' Performance Indicators and Benchmarking Network Project database of the Water Utilities Partnerships of Africa. Although the database comprised data collected in the year 2000 from 110 water utilities in Africa, the data for this study were collected from up to 84 utilities in 13 countries in SSA, of which 14 utilities were managed under PPPs. ${ }^{16}$ The PPPs were management, lease or concession contracts in the countries of Cameroon, Cape Verde, Côte 
d'Ivoire, Gabon, Ghana, Kenya, Morocco, Nigeria, Republic of Guinea, Senegal, South Africa, Tunisia and Zambia. The range of performance indicators used included labour productivity, proportion of operating costs spent on fuel and chemicals, rate of capital utilisation, average tariffs, percentage of population served, non-revenue water, and hours of availability of service per day. ${ }^{16}$ Using $F$-tests, stochastic frontier and data envelopment analyses, the study found that, when crosscountry heterogeneity in the political, legal and economic environment was controlled, there was no strong evidence that water utilities being managed under PPP contracts performed better than those exclusively operating under public law. ${ }^{16}$

A recent study carried out by the World Development Movement found that one of the key reasons for lack of performance improvement by PPPs in SSA is that they have not dedicated adequate funds to improve the service quality. ${ }^{7}$ Most of the PPP contracts operating in SSA, notably lease and management contracts, do not cater for investment by the private sector in extending services. Furthermore, the investment commitments agreed under the few concession contracts operating in SSA have been revised, abandoned or missed. There are several case studies in the literature that may illustrate this point. In Libreville, the capital of Gabon, which is serviced by a PPP consortium led by Veolia, the utility's underinvestment was blamed for failure to connect new households, long interruptions in supply and poor water quality. ${ }^{7,19}$ In Mali, a 20-year concession was awarded to Saur (a French international water operator) in 2000, with the major objective of making significant expansions in service coverage, and improving the technical and financial performance. But Saur was unable to raise the required investment funds to fulfil its contractual obligations, leading to the Government's drastic decision to renationalise the company. ${ }^{7,20,21}$ The story is not much different with utilities managed under concession contracts in South Africa (Dolphin Coast and Nelspruit) where the PPP contracts were distressed mainly because the private company was not investing enough funds for improving service quality. $^{7,14}$

In general, PPPs have the potential to improve some aspects of performance. The private sector's technical and managerial competences, combined with sustainable pricing policies and better financial discipline, would enhance the effectiveness and efficiency of service provision. Furthermore, it was anticipated that extra investment funds obtained from the private sector would be injected into improvement of service quality. However, findings from most studies quoted in the literature, some of which have been described in the preceding paragraphs, show that water utilities under PPPs are not necessarily more effective and efficient than those under public management. One key factor that compounds the relationship between efficiency gains and PPPs is the type of competition that is dictated by the unique characteristics of water services, as discussed in Section 3.

Whereas market competition is feasible in telecommunications and parts of energy such as power generation, the technology of water services and the nature of water as a product restrict the prospect of efficiency gains through market competition. Huge investment requirements for installing parallel reticulation networks, and water-quality implications of mixing water from different supply networks, place a serious restriction on suppliers' competition for water service customers. ${ }^{15,16}$
Compared to market competition, tender competition, the most dominant type of competition in water services provision, requires a more distinct presence of effective institutions that play the key roles of referees and judges as a prerequisite for performance improvement. ${ }^{22}$ However, PPPs in SSA were often launched in a regulatory vacuum, as many countries do not have infrastructure services regulators, courts specialising in PPP contracts, or similar bodies to act as arbitrators. ${ }^{10}$ In countries where the necessary institutions are in place, they may either be corrupt or inefficient in setting or enforcing standards. A good and recent example of the latter are events that led to the cancellation of the 30-year concession contract for service provision in Buenos Aires, Argentina, in mid-2006: poor service levels, tariff increases and low investment in infrastructure expansion were attributed to excessive state interference, poor regulatory capacity and perceived bias for the regulated firm. ${ }^{23}$ It should be borne in mind that regulatory functions are necessary whether services are being delivered under PPPs or public management. It seems that the quality of regulation, rather than level of private sector participation, is a critical success factor for determining the extent to which pressures for efficiency are maintained on the service provider. ${ }^{3}$ The next section presents a case study from Uganda, which shows that performance of the National Water and Sewerage Corporation (NWSC) in Kampala (the capital city) did not improve as anticipated when it was managed under PPP. On the other hand, NWSC has made huge gains in efficiency during the past few years under public management.

\section{THE KAMPALA (UGANDA) PPP CASE STUDY}

Unless otherwise stated, the material used in this section has exclusively been drawn from a forthcoming World Bank Working Paper on the transformation of NWSC. ${ }^{24}$ Water and sewerage services in Kampala (2002 population of 1208 504), the capital city of Uganda, are provided by NWSC, a government-owned corporatised firm, which was established by the then military government's Decree No. 34 of 1972. NWSC's legal position was strengthened by the NWSC Statute No. 7 of 1995, later by the NWSC Act of 2000, and was mandated to provide water and sewerage services to the country's major towns, currently numbering 22, on a cost-recovery basis. The other key player in Uganda's water sector is the Directorate of Water Development, which is mandated to provide water services to rural areas and small towns (with less than 20000 people). Since 1998, the water sector has been undergoing reform, aimed at clearly separating the functions of operations, asset holding/management and regulating/overseeing. To date this reform process has not yet been finalised. However, owing to the historical loans obtained by NWSC for infrastructure expansion, which were guaranteed by the government, NWSC has since the late 1990s been put under the oversight of the Utility Reform Unit of the Ministry of Finance and Economic Planning.

When NWSC operated in only the three largest towns of the country (i.e. Kampala, Jinja and Entebbe), its performance could easily be classified as being fairly average. As the Government of Uganda rehabilitated and expanded infrastructure in the smaller towns and obliged NWSC to take them over, the capital costs passed on to NWSC, coupled with the eroded economies of scale, created a financial burden to the utility. Furthermore, the high disparity in income levels between households in primary 


\begin{tabular}{|c|c|c|c|c|c|c|}
\hline & \multicolumn{2}{|c|}{ 1998/1999 } & \multicolumn{2}{|c|}{$1999 / 2000$} & \multicolumn{2}{|c|}{$2000 / 2001$} \\
\hline & Target & Actual & Target & Actual & Target & Actual \\
\hline Billing efficiency: \% & 45 & 49 & 52 & 56 & 65 & 53 \\
\hline $\begin{array}{l}\text { Billings: } \\
\text { Ushs million }\end{array}$ & 22372 & 16911 & 25016 & 16233 & 32410 & 20426 \\
\hline $\begin{array}{l}\text { Collections: } \\
\text { Ushs million }\end{array}$ & 17898 & 18348 & 20763 & 15705 & 27549 & 24306 \\
\hline Collection ratio: \% & 80 & 109 & 83 & 97 & 85 & 119 \\
\hline
\end{tabular}

and secondary towns meant that customers in the new service areas generally had a lower ability and willingness to pay for increased service levels. By 1997, NWSC's financial forecasts were quite bleak: not only was it experiencing operating deficits but it was shortly expected to start servicing the investment loans, to the tune of over US\$100 million. These developments were taking place in NWSC's internal environment at the time when adoption of PPPs in developing countries which were marketed by international financial institutions as the saviour of poor utility performance, was at a peak. NWSC's management and other policy makers in the Ugandan water sector therefore perceived a management contract with an international water operator as an opportunity to correct the prevailing weaknesses and deter potentially devastating threats.

Characteristic of many first-generation PPPs in developing countries, NWSC hastily negotiated the management contract with H P Gauff, a German technical consulting firm, without going through a full tendering process, with confidence based on the fact that H P Gauff was participating in a similar contract in Malindi, in neighbouring Kenya. What they did not take into consideration was the fact that these management contracts were running at about the same time, H P Gauff was venturing into utility management for the very first time, and it was unlikely for the contractor to transfer effectively knowledge and skills obtained from Malindi, a comparatively smaller city, to Kampala, a larger city. The hasty procurement process had several key implications. First, since it was single-sourcing, the process missed out on competencies inherent in the competition for the market. Second, the skills and the available time were inadequate for collecting the necessary baseline data for effective contract negotiation and subsequent monitoring and evaluation. Third, many stakeholders were not given enough time to internalise the process and buy into the whole PPP concept. Fourth, the hasty nature also became a breeding ground for accusation of rent-seeking during the procurement process. Finally, inadequate time was available to set up and train a team to monitor and evaluate the project.

The three-year management contract, called the Kampala revenue improvement project, started in 1998. Its major objectives were to improve revenue collection, reduce water loss in the reticulation network, and increase service coverage. Therefore the scope of the management contract was limited to operations of water distribution and sales, but excluded water production and sewerage services. The client retained responsibilities for financing the operational costs (inclusive of staff costs), and contract monitoring was governed on the basis of cost of service. This approach to contract management did not provide enough incentives for the operator to contain costs. Furthermore, the fact that the client retained most functions of personnel management meant that the operator could not control the staff. The ill-defined performance targets and the poor structure monitoring system meant that there was not enough pressure to bear on the contractor to improve operational efficiency. Performance targets were evaluated on a yearly basis, and Table 3 shows the trends for the revenue collection function, with modest improvements as per set targets. Similarly, service coverage was reported to have improved from 51 to 57\% between 1998 and 2001. However, most of the data were difficult to verify, especially so as the baseline data were not accurately obtained.

When the Kampala revenue improvement project contract ended, NWSC senior managers and other key policy makers in the water sector evaluated the whole experience as part of adaptive learning. These lessons were applied to undertake modifications in the design, procurement and implementation of the subsequent two-year management contract with Ondeo International (formerly Lyonnaise des Eaux) that ran from 2002 to 2004. The contractor registered a local company, Ondeo Services Uganda Ltd (OSUL). The following key changes were made to ensure higher levels of performance from the OSUL management contract.

(a) The procurement process took about 18 months, and used international competitive bidding.

(b) More NWSC managers were involved in the procurement process, hence securing better buy-in and understanding.

(c) The contractor took full charge of both the water distribution and wastewater collection, leaving out water production and sewage disposal.

(d) The contractor took full control of the staff seconded to the project.

(e) The contract incorporated an operational investment fund, dedicated for network rehabilitation, which was mainly funded by Kreditanstalt für Wiederaufbau (KFW), a German international development agency.

(f) The contract incorporated a performance incentive fee based on billings, collections, non-revenue water and service access.

(g) There were quarterly reviews, with the contractor required to provide process-oriented reports.

Table 4 shows performance trends during the Kampala OSUL management contract. On the whole the performance was better than during the previous contract. The table shows that the revenue collection targets were met, although billings were 


\begin{tabular}{|c|c|c|c|c|c|}
\hline \multirow[t]{2}{*}{ Performance standard } & \multirow{2}{*}{$\begin{array}{c}\text { Base year } \\
2001\end{array}$} & \multicolumn{2}{|c|}{ Year I: 2002-2003 } & \multicolumn{2}{|c|}{ Year 2: 2003-2004 } \\
\hline & & Target & Actual & Target & Actual \\
\hline Water billed: $\times 10^{6} \mathrm{~m}^{3}$ & 1562 & 1765 & 1655 & $1952 \cdot 5$ & 1736.7 \\
\hline Non-revenue water: \% & $44 \cdot 5$ & $39 \cdot 8$ & $44 \cdot 4$ & $35 \cdot 7$ & $45 \cdot 5$ \\
\hline Average monthly billings: Ushs million & $1611 \cdot 4$ & $1820 \cdot 9$ & 1818.5 & $2014 \cdot 3$ & $2006 \cdot 3$ \\
\hline Average monthly collections: Ushs million & $1567 \cdot 8$ & $1900 \cdot 6$ & $1805 \cdot 6$ & $2123 \cdot 1$ & $1914 \cdot 1$ \\
\hline Active water connections & 33050 & 39070 & 38659 & 46840 & 45722 \\
\hline Inactive water connections & 10783 & 8760 & II 637 & 6920 & 12445 \\
\hline Total water connections & 43833 & 47830 & 50296 & 53760 & 58167 \\
\hline Connection efficiency: \% & $75 \cdot 4$ & $81 \cdot 7$ & 76.9 & $87 \cdot 1$ & $78 \cdot 6$ \\
\hline Metering efficiency-actual: \% & $90 \cdot 5$ & $90 \cdot 9$ & $92 \cdot 6$ & $93 \cdot 0$ & $94 \cdot 6$ \\
\hline Average monthly new connections & 473 & 525 & 506 & 580 & 681 \\
\hline
\end{tabular}

much boosted by the tariff adjustments of 4 and 5\% in 2003 and 2004, respectively. The rate of increase of new connections improved from a monthly average of 473 in the first year to 681 in the second year. However, despite the injection of substantial funds in the reticulation network, the key performance indicator for reduction of non-revenue water was not achieved. Another target that fell short was connection efficiency, defined as the proportion of active to total connections, which shows how many customers were disconnected mainly due to non-payment of water bills. There was a general feeling within NWSC that OSUL would have performed better if they had not spent about half of the contract time and the bulk of the operational investment fund on merely carrying out baseline studies.

The implementation of OSUL enabled NWSC staff to consolidate their knowledge and skills in PPP procurement, contract design and implementation. The real experience was supplemented by short courses attended by key staff on relevant topics such as contract procurement and management, negotiation skills, etc. These skills became handy when the contractor demanded a renegotiation seeking a 20\% increase in the management fee in the first year of the contract, and during negotiations for extension of the contract. The latter negotiations were carried out based on a detailed cost-of-service analysis of all production processes carried out by NWSC. After consultations with their head office, OSUL opted against extension of the contract, and finally handed over the management of the service area back to NWSC in February 2004.

After five years of PPPs, Kampala water supply area was 'received back in the main fold' of NWSC's directly-managed towns, which at the time were benefiting from a series of short-term change management programmes to improve performance. These programmes were started in 1998, by a newly appointed managing director, who found an internal environment dominated by low revenue collections, increasing deficits of working capital, stagnant numbers of customers, a high non-revenue water proportion and a demoralised staff. In the external environment, there were a high number of illegal connections, negative public relations and an impeding obligation to start servicing a huge loan. The new managing director rallied the staff towards short-term change management programmes with the overall objective of increasing operational and financial efficiency. The main focus areas were improving water production and sewage treatment capacity, increasing efficiency in water distribution, particularly with respect to non-revenue water, improving revenue collection, cost reduction, and enhancement of customer care.

The change programmes were codenamed, in a chronological order, 100-days programme, the service and revenue enhancement programme, area performance contracts and internally delegated management contracts. Area performance contracts were six-monthly internal contracts that NWSC senior management initiated in which many operational tasks were delegated by the centralised service areas, and where incentives/ disincentives were closely pegged to prescribed performance levels. With time, area performance contracts evolved into longer-term internally delegated management contracts, in which the areas became more autonomous in the functional tasks.

On the external front, NWSC negotiated a three-year performance contract with the Government of Uganda in 2000, which brought into operation the conditions set for the debt freeze. This contract was renewed for the second and third terms. NWSC's contract with the government formed the framework for the NWSC head office to design area performance contracts and internally delegated management contracts with the decentralised service areas. NWSC head office was duly declared as an asset-holding authority in 2004. The changes in the external and internal environment of NWSC have mirrored the concepts from the new public management paradigm with the following characteristics that are specific to water services. $^{25}$

(a) Increasing the level of autonomy of the utility.

(b) Separating regulatory tasks from service provision.

(c) Creating quasi-competition in the water sector.

(d) Increasing tariffs to cost-recovering levels and ensuring that staff aim to increase customer satisfaction.

(e) Increasing accountability for the results produced by the utility.

The results of these change management programmes have been amazing. The operational performance of NWSC has improved tremendously and NWSC has recently been lauded as a utility of good practices in the region, and has been working with other 


\begin{tabular}{|c|c|c|c|c|}
\hline & 1998 & 2000 & 2003 & 2006 \\
\hline Non-revenue water: \% & $55 \cdot 0$ & 43 & 39 & 31 \\
\hline Staff productivity: staff/I000 connections & 36.0 & 18 & 12 & 7 \\
\hline Proportion of inactive accounts to total accounts: \% & 38.6 & 26 & 21 & 12.2 \\
\hline Collection ratio: \% & $60 \cdot 0$ & $89 \cdot 3$ & 95 & 98 \\
\hline Metering efficiency: \% & 73 & 82 & 95 & 99 \\
\hline Total number of accounts & 50826 & 62348 & 93596 & 166692 \\
\hline Service coverage: $\%$ of population served & 48 & 56 & 62 & 70 \\
\hline Operating surplus: US $\$ 10^{3} /$ month & $(300 \cdot 0)$ & 195 & 500 & 926 \\
\hline
\end{tabular}

utilities in the region to apply these approaches for their own benefit. Table 5 shows performance trends for NWSC since 1998 when the innovative management approaches started. It should be noted that this performance is aggregated for all the service areas under NWSC, and Kampala accounts for over 60\% of the business turnover. The table shows that performance between 2003 and 2006, when NWSC was in charge of Kampala, was increasing at a higher rate than previously when Kampala, the main service area, was managed under PPPs.

The Kampala case study results confirm the theory suggested in various publications that PPPs have a smaller effect on performance improvement of a water utility, compared to other context-specific factors. Other factors that may have a stronger effect include ${ }^{26}$

(a) an adequate degree of external autonomy

(b) full political support to strike a delicate balance between political and financial objectives of the organisation

(c) effective regulatory structures that ensure internal and external accountability

(d) customer orientation philosophy of utility staff.

A critical success factor is the high skills level of the human resources, an area that NWSC has been investing in heavily since the early 1990s. Another key success factor is a dedicated, visionary and foresighted leadership to coordinate and harmonise the human and other organisational resources in order to better leverage the utility's strengths, correct its weaknesses, capitalise on opportunities and deter potentially devastating threats.

\section{CONCLUSION}

Key justifications of international financial agencies to compel water utilities in SSA to take on PPPs were the need to attract the much needed capital financing for water services infrastructure, and the prospect of performance improvement under PPPs. This paper has reviewed the literature on performance of water utilities in SSA, which shows that neither of these has been automatic for many utilities operating under PPPs in SSA. The type of PPPs commonly operating in SSA are management and lease contracts, which do not entail investment funding on the part of the operator. The literature presents mixed results, with no strong evidence showing the link between PPPs and performance improvement. A case study on Kampala, Uganda, has shown that performance improvements of NWSC, the utility in Kampala, were not as high as expected when it was twice managed by different international operators. On the other hand, NWSC has made impressive performance improvements under the current public management model. Although not conclusive, the results from the literature and the case study seem to point to a greater importance of context-specific factors. There is a need for further research into the effects of an appropriate level of external autonomy, commercial orientation, existence of regulatory systems to ensure internal and external accountability, customer orientation, human resource development and a visionary leadership.

\section{ACKNOWLEDGEMENT}

The author is grateful to the authors of the forthcoming World Bank water sector board discussion paper series paper entitled Transforming Public Water Utilities through Private Sector-like Management Principles: the National Water and Sewerage Corporation, Uganda Experience, for providing access to their database. Further gratitude goes to Mr Dennis Mwanza, former Managing Director of Water Utilities Partnerships of Africa, for cross-checking the information presented in Table 2.

\section{REFERENCES}

1. United Nations (UN). The Millennium Development Goals Report 2007. United Nations, New York, 2007.

2. UN-HABITAT. State of the World's Cities, 2004/05. UNHABITAT, Nairobi, Kenya, 2004, UN-HABITAT report.

3. HARRIS C. Private Participation in Infrastructure in Developing Countries: Trends, Impacts and Policy Lessons. The World Bank, Washington, DC, 2003, World Bank Working Paper No 5.

4. Nellis J. The evolution of enterprise reform in Africa: from state-owned enterprises to private participation in infrastructure-and back? 2005, FEEM Working Paper No. 117.05. Available at http://papers.ssrn.corn/ abstract=828764. Accessed 27/11/2008.

5. DARRIN G. and LeWIS M. K. Evaluating the risks of public private partnerships for infrastructure projects.

International Journal of Project Management, 2002, 20, No. 2, 107-118.

6. FRANCEYS R. Private Sector Participation in the Water and Sanitation Sector. WEDC, Loughborough University, UK, 1997, Occasional Paper No. 3.

7. Hall D. and Lobina E. Pipe Dreams: the Failure of the Private Sector to invest in Water Services in Developing Countries. World Development Movement, London, 2006.

8. World Health ORganisation and UNICEF. Meeting the MDG Drinking Water and Sanitation Target: the Urban and Rural Challenge of the Decade. WHO/UNICEF, Geneva, 2006. 
9. International Policy Centre, UNDP. Privatising Basic Utilities in Sub-Saharan Africa: the MDG Impact. International Policy Centre, Brazilia, 2007, Research Brief No. 3.

10. BRAADBAART 0. Privatizing water and wastewater in developing countries: assessing the 1990s' experiments. Water Policy, 2005, 7, No. 4, 329-344.

11. SILVA G. F. Tolls Roads: Recent Trends in Private Participation. The World Bank, Washington, DC, 2000, Public Policy for the Private Sector, Note No. 224.

12. WORLD BANK. Reforming Infrastructure: Privatization, Regulation, and Competition. Oxford University Press, Oxford, 2004, World Bank Policy Research Report.

13. World BANK. Private Participation in Infrastructure Projects Database, Public Private Infrastructure Advisory Facility. The World Bank, Washington, DC, 2007.

14. BAYLISS K. Utility privatisation in Sub-Saharan Africa: a case study of water. Journal of Modern African Studies, 2003, 41, No. 4, 507-531.

15. PARKER D. and KIRKPATRICK C. Privatisation in developing countries: a review of the evidence and the policy lessons. Journal of Development Studies, 2005, 41, No. 4, 513-541.

16. KIRKPATRICK C., PARKER D. and ZhANG Y. An empirical analysis of state and private-sector provision of water services in Africa. The World Bank Economic Review, 2006, 20, No. 1, 143-163.

17. ESTACHE A. and Rossi M. How different is the efficiency of public and private water companies. The World Bank Economic Review, 2002, 16, No. 1, 139-148.

18. Clarke R. and WALlSTEN S. J. Universal(ly bad) Service: Providing Infrastructure Services to Rural and Poor Urban
Consumers. The World Bank, Washington, DC, 2002, Policy Research Working Paper 2868.

19. Africa News. Privatized water company runs into supply problems. Africa News, 24 January 2005.

20. Balance T. and Tremolet S. Private Sector Participation in Urban Water Supply in Sub-Saharan Africa. German Development Cooperation, Frankfurt, 2005.

21. World Markets Analysis. French services giant ejected from Mali water privatization. World Markets Analysis, 2005, 1 December.

22. Moor M. Competition within and between organisations. In Managing Development: Understanding Inter-organisational Relationships (Robinson D., Hewitt T. and Hattis J. (eds)). The Open University, Milton Keynes, 2000.

23. Casarin A. A., Delfino J. A. and Delfino M. E. Failure in water reform: lessons from the Buenos Aires concession. Utilities Policy, 2007, 15, No. 4, 234-247.

24. Mugisha S., Marin P., MuhairWe S. and Mugabi J. Transforming Public Water Utilities through Private Sectorlike Management Principles: the National Water and Sewerage Corporation, Uganda Experience. The World Bank, Washington, DC, World Bank Water Sector Board Discussion Paper (forthcoming).

25. Schwartz K. The New Public Management: the future for reforms in the African water supply and sanitation sector? Utilities Policy, 2008, 16, No. 1, 49-58.

26. BaietTI A., Kingdom B. and VAN GinNEKEN M. Characteristics of Well-performing Public Utilities. The World Bank, Washington, DC, 2006, Water Supply and Sanitation Working Paper 9.

\section{What do you think?}

To comment on this paper, please email up to 500 words to the editor at journals@ice.org.uk

Proceedings journals rely entirely on contributions sent in by civil engineers and related professionals, academics and students. Papers should be 2000-5000 words long, with adequate illustrations and references. Please visit www.thomastelford.com/journals for author guidelines and further details. 